\title{
Comparison of pathological and healthy indicators of Zulliger with R-optimized administration
}

\author{
Anna Elisa de Villemor-Amaral ${ }^{1}$ \\ iD http://orcid.org/0000-0002-1815-8194 \\ Gabriel Vitor A. Gomes ${ }^{1}$ \\ iD http://orcid.org/0000-0001-6565-3094
}

\begin{abstract}
How to cite this article: Villemor-Amaral, A. E., \& Gomes, G. V. A. Comparison of pathological and healthy indicators of Zulliger with R-optimized administration. Psicologia: Teoria e Prática, 22(3), 37-54. doi:10.5935/1980-6906/psicologia.v22n3p37-54
\end{abstract}

Submission: 07/05/2019

Acceptance: 06/23/2020

The content of Psicologia: Teoria e Prática is distributed under the terms of the Creative Commons Attribution License.

1 São Francisco University (USF), Campinas, SP, Brazil. 


\begin{abstract}
In the Zulliger test, traditionally, there is no control over the number of answers, but a low number of responses influences the interpretation of variables. Considering as model the R-optimized administration proposed to the Rorschach Performance Assessment System, we adapted the traditional way of Zulliger administration in order to control the number of responses in Zulliger. The objective was to verify the differences in some pathological and healthy variables in a group of patients with several psychopathologies and non-patients with an optimized range of responses in Zulliger. One hundred twelve people participated, divided equally: Group 1 of patients with a psychopathological diagnosis ( $82.1 \%$ female, $M=39.34$ years old, $\mathrm{SD}=13.81$ ), and Group 2 of people without a diagnosis ( $60.7 \%$ female, $M=31.30$ years old, SD $=9.37)$. Results indicated statistically significant differences $(p<0.05)$ between groups in seven variables, with effects ranging from moderate to strong in magnitude. We concluded that, with the control of responses, the Zulliger variables were able to differentiate the groups and XA\% and WDA\% were the main findings of the study.
\end{abstract}

Keywords: projective personality measures; psychopathology; psychological assessment; psychometrics; statistical analysis.

\title{
COMPARAÇÃO DE INDICADORES PATOLÓGICOS E SAUDÁVEIS DO ZULLIGER COM ADMINISTRAÇÃO R-OTIMIZADO
}

Resumo

No teste de Zulliger, tradicionalmente não há controle na quantidade de respostas, mas um número baixo de respostas influencia a interpretação das variáveis. Tomando como modelo a administração R-otimizado do Rorschach Performance Assessment System, fez-se uma adaptação para controlar o número de respostas dadas no Zulliger. Objetivou-se verificar a existência de diferenças em algumas variáveis patológicas e saudáveis em um grupo de pacientes (diversas psicopatologias) e não pacientes com uma faixa otimizada de respostas no Zulliger. Participaram 112 pessoas, divididas igualmente: grupo 1 de pacientes com diagnóstico psicopatológico (82,1\% feminino; $M=39,34$ anos; $D P=13,81)$ e grupo 2 de pessoas sem diagnóstico (60,7\% feminino; $M=31,30$ anos; $D P=9,37)$. Os resultados indicaram diferenças estatisticamente significativas $(p<0,05)$ entre os grupos em sete variáveis, com efeitos variando de magnitude moderada a forte. Concluiu-se que, com a faixa oti- 
mizada de respostas, as variáveis do Zulliger foram capazes de diferenciar os grupos, e XA\% e WDA\% foram os principais achados do estudo.

Palavras-chave: medidas projetivas da personalidade; psicopatologia; avaliação psicológica; psicometria; análise estatística.

\title{
COMPARACIÓN DE INDICADORES PATOLÓGICOS Y SALUDABLES DE ZULLIGER CON ADMINISTRACIÓN R-OPTIMIZADO
}

\begin{abstract}
Resumen
En el teste de Zulliger normalmente no hay control en la cantidad de respuestas, pero un numero bajo influye en la interpretación de las variables. Tomando como modelo la administración R-optimizado del Rorschach Performance Assessment System, se hizo una adaptación para controlar respuestas en Zulliger. El objetivo fue verificar la existencia de diferencias en algunas variables patológicas y saludables en un grupo de pacientes (diversas psicopatologías) y no pacientes con una faja optimizada de respuestas en Zulliger. Participaron 112 personas, divididas igualmente: grupo 1 pacientes con diagnóstico psicopatológico (82,1\% femenino; $M=39,34$ años; $D P=13,81$ ) y grupo 2 personas sin diagnóstico (60,7\% femenino; $M=31,30$ años; $D P=9,37)$. Resultados indicaron diferencias estadísticamente significativas $(p<0,05)$ entre los grupos en siete variables, con efectos variando de magnitud moderada a fuerte. Concluyese que con la faja optimizada de respuestas las variables del Zulliger fueron capaces de diferenciar los grupos, XA\% y WDA\% las principales descubiertas del análisis. Palabras clave: medidas proyectivas de la personalidad; psicopatología; evaluación psicológica; psicometría; análisis estadístico.
\end{abstract}

\section{Introduction}

Psychology professionals can contribute to the health process of individuals with psychopathological disorders. There are psychological assessments among possibilities for professional practice, which consist of structured processes to investigate psychological phenomena among individuals, groups, or institutions to answer a specific demand to make decisions (Hutz, 2015; Urbina, 2007). Therefore, psychological assessments are an essential strategy in the investigation process of individuals' pathological functioning and can contribute to an improved quality of life.

The psychological assessment process must include various resources such as psychological tests, which are essential tools to tap into information that is not 
always accessible through speech or observation (Hutz, 2015). Psychological tests include projective techniques such as tasks in which individuals are asked to draw, tell stories, build pyramids with colored squares, and tell what an inkblot looks like, among others. These tasks have instructions that are sufficiently open to allow individuals to provide answers based on their style and are characterized by being difficult to manipulate, that is, the respondents do not know what the right or wrong answers are. Therefore, projective methods offer a possibility to assess one's personality, psychopathological symptoms, and other characteristics not readily accessible when using other strategies (Cardoso \& Villemor-Amaral, 2017; Fensterseifer \& Werlang, 2008).

Among the projective techniques, there is the Zulliger test. This test is used to assess the cognitive and emotional aspects of personality and was created by the Swiss psychologist Hans Zulliger in the context of the World War II, having as reference the Rorschach's method (Zulliger \& Salomon, 1970; Villemor-Amaral \& Primi, 2009). Literature reviews show the use of Zulliger in the assessment of children, adult and elderly individuals (Cardoso, Gomes, Pacheco, \& Dias-Viana, 2018; Grazziotin \& Scortegagna, 2016) and it is also commonly used among patients with depression, schizophrenia, obsessive-compulsive disorder, panic disorder, somatoform disorder, and alcoholic disorder (Franco \& Villemor-Amaral, 2009, 2012a, 2012b; Villemor-Amaral \& Machado, 2011). This instrument can support an understanding of personality characteristics related to psychopathologies in a diagnostic process (Villemor-Amaral \& Primi, 2009).

The studies using the Zulliger among groups of patients were conducted according to the Comprehensive System, initially developed for the Rorschach's method (Exner \& Sendín, 1999), in which the number of answers provided by the respondents is not controlled. Due to criticism regarding this system's scientificity in the Rorschach test, new studies were conducted and culminated with the manual Rorschach Performance Assessment System, published in 2011 - R-PAS (Meyer, Viglione, Mihura, Erard, \& Erdberg, 2017).

The administration used in the R-PAS is called R-Optimized Administration, in which participants are asked to provide two or three responses per card to reduce variability in the number of responses and consequent impact in the instrument's psychometric quality. This administration prevents short or long protocols, estimating an optimized range between 18 and 27 responses, decreasing distortions 
interpreting the remaining variables, and improving the stability of indicators (Dean, Viglione, Perry, \& Meyer, 2007; Meyer et al., 2017).

Concerning the Zulliger test, an attempt to control the number of responses emerge specifically to avoid concise protocols, because, as previously mentioned (Villemor-Amaral \& Cardoso, 2012; Villemor-Amaral, Pianowski, \& Carvalho, 2016), a low number of answers influence the instrument's remaining variables and seems to decrease the validity of the results. In the study by Villemor-Amaral et al. (2016), the authors state that the protocols of the Zulliger with six or fewer responses have its interpretation compromised, suggesting that a protocol should have at least nine answers for obtaining results consistent with other measures. Thus, they suggest adapting the administration of Zulliger and propose an R-optimized model similar to R-PAS.

Initial studies used an adaptation of the R-optimized administration to verify the viability of using it with Zulliger in samples of patients. This adaptation asks from three to five responses per card, eliciting a higher number of answers, so that the test's three cards elicit from nine to 15 answers in the protocol as a whole (Gonçalves \& Villemor-Amaral, manuscript submitted for publication; Gonçalves, Zuanazzi, \& Villemor-Amaral, 2019). Note that the two studies have different proposals and were conducted with the same database.

The study by Gonçalves and Villemor-Amaral (manuscript submitted for publication) was intended to compare the frequency of codes related to depression in the Zulliger according to the R-optimized administration between a group with depression and a group with no depression. A total of 86 people participated, 43 of whom had a diagnosis of depression ( $88 \%$ women, aged 35.8 years old on average), and 43 people did not have a diagnosis of depression (84.4\% women, aged 35.7 years old on average). The results show significant statistical differences $(p<0.05)$ in the variables of mixed determinants, the sum of achromatic color responses $\left(C^{\prime}\right)$, pure color responses (C), and the special codes morbid (MOR) and aggressive (AG). These results were more satisfactory than those obtained in the studies by Villemor-Amaral and Machado (2011) and Franco and Villemor-Amaral (2012a) so the authors concluded that the Zulliger applied with R-optimized administration provides a more significant contribution to understand how people with depression function, opening up the possibility of conducting similar studies with individuals with other psychopathologies. 
Gonçalves et al. (2019) sought evidence to validate Zulliger using the adapted R-optimized administration by associating Rorschach in the variables related to depression. A total of 39 individuals, mostly women (83.2\%), diagnosed with depression and aged between 18 and 62 years old $(M=34.90 ; S D=11.54)$, participated in the study. As expected, the results show an increase in the number of responses provided in the Zulliger $(M=9.9 ; S D=1.63)$ and correlations from moderate to strong ( 0.32 to 0.77 ) were found between the Zulliger's and Rorschach's variables, namely, shading determinants and their sum ( $C^{\prime}, T, Y$, and $r$ ), mixed color and shading determinants egocentrism and intellectualization indexes, botany (Bt) and art (Art) content, and even answers (2). The authors concluded that the study collaborated with the initial evidence of validity to some selected variables and suggested that future studies asked different samples to complete the Zulliger with administration according to the Comprehensive System and the R-optimized adaptation to compare both and see which presents the best results.

Considering the initiative to adapt the R-optimized administration for the Zulliger, in this study, differences were found in some pathological and healthy variables in a group of patients (different psychopathologies) and non-patients with an optimized range of answers. The hypothesis is that the Zulliger applied with the R-optimized administration will discriminate between the groups. Hence, the group of patients is expected to present higher means in the variables related to psychopathological evidence, and the non-patient group is expected to present higher means in the codes with an interpretation of healthy psychological functioning. With this objective in mind, a previous analysis was conducted between two psychopathological groups to verify whether this study's results were due to the change proposed in the Zulliger administration. One group completed the instrument according to the R-optimized administration, and the other group completed it without controlling for the number of responses.

\section{Method}

\subsection{Participants}

This study addressed individuals from two different surveys. The first database was composed of 39 individuals with a psychopathological diagnosis of 
depression (database 1), and the second database included 475 individuals with and without a psychopathological diagnosis (database 2). These databases had been used in studies conducted in the Laboratório de Avaliação Psicológica em Saúde Mental (LAPSaM) [Mental Health Psychopathological Assessment Laboratory]. Note that the first study was administered with R-optimized administration, and the data from the second study were collected according to the Comprehensive System's instructions, that is, without controlling for the number of responses.

The participants in the stage in which psychopathological patients were compared to were allocated into two groups. The first was composed of 39 individuals, most of whom were women (87.2\%) aged 35 years old on average $(S D=11.56)$. This group completed the instrument according to the R-optimized instructions. The second group was 39 individuals; mostly women (84.6\%) were 41.97 years old on average $(S D=11.37)$, who completed the instrument without controlling for the number of responses.

For the second stage, individuals who had provided between nine and 15 answers were selected from the LAPSaM database. This range of answers was chosen to meet the criterion of the number of answers expected when the $\mathrm{R}$-optimized administration is used. A similar strategy was adopted in other studies to compose the database in which the individuals did not answer the instrument controlling for the number of answers (Dean et al., 2007; Meyer et al., 2017).

Hence, Group 1 was composed of 56 patients diagnosed with depression, alcoholism, schizophrenia, panic disorder, somatoform disorder, and obsessivecompulsive disorder. Most individuals in this group were women (82.1\%) aged 39.34 years old on average $(S D=13.81)$. Group 2 was composed of 56 individuals with no diagnosis; mostly women $(60.7 \%)$ aged 31.30 years old $(S D=9.37)$.

\subsection{Instrument}

The Zulliger test (Villemor-Amaral \& Primi, 2009) is a projective test used to assess one's personality cognitive and emotional aspects and consists of three cards with inkblots that serve as stimuli. The task is individually performed and is divided into two phases: Response Phase and Clarification Phase. In the Response Phase, the cards are presented in a standardized sequence, and individuals answer the question, "What does it look like?." In the Clarification Phase, the cards are shown again, and the examiner reads the answers while the individual tells where 
$\mathrm{s} /$ he saw that and what in the inkblot made it look like it. After the administration, the answers are coded, which enable calculations that lead to interpretations of an individual's characteristics. Seventy-one variables result from this coding, which compose the system of analysis and interpretation of Zulliger. The precision indexes between the evaluators in the coding process ranged from poor (values $<0.20$ ) up to very good (values $>0.81$ ), with most variables obtaining from moderate to very good indexes (between 0.41 and 0.60 ). Due to the number of variables, we suggest consulting the manual to identify each variable's specific value (Villemor-Amaral \& Primi, 2009).

The variables used in similar studies were selected (Franco \& VillemorAmaral, 2009, 2012a, 2012b; Gonçalves \& Villemor-Amaral, manuscript submitted for publication; Gonçalves et al., 2019; Villemor-Amaral \& Machado, 2011) from a total of 71 simple frequency count variables, as well as ratios, percentages, and derivations. The variables refer to changes in thinking and perception that indicate that relationships with others are compromised.

The variables related to psychopathological indicators are the weighted sum of special codes (WSum6), aggressive movement (AG), morbid content (MOR), poor human representation (PHR), experienced stimulation (es), percentage of answers with less formal quality (X-\%), chromatic color response (Sum C), Egocentrism index and Isolation index. The variables most frequently linked to healthy functioning are the total number of answers $(R)$, cooperative movement (COP), good human representation (GHR), percentage of less formal quality (XA\%), percentage of answers in common areas without less formal quality (WDA\%), percentage of answers with uncommon formal quality (Xu\%), and popular answers (P) (Villemor-Amaral \& Primi, 2009; Exner \& Sendín, 1999).

\subsection{Procedures}

The protocols come from a database originating from two studies that had been previously approved by the Research Ethical Committee, and all the participants signed free and informed consent forms. Data were collected individually and by various researchers involved in the studies promoted by the LAPSaM, Universidade São Francisco (USF). Please refer to the original studies for further details concerning ethical procedures and data collection (Gonçalves et al., 2019; Villemor-Amaral \& Primi, 2009). 
For this study, data were organized in an Excel 2016 spreadsheet and then exported to the JASP program Version 0.9.2 (JASP Team, 2018) to conduct the descriptive analysis and characterize it. Afterward, the two groups were compared using the Student's t-test, with significance established at $p<0.05$ and the respective magnitudes of Cohen's $d$, to check the frequency of variables in the different groups. These analyzes were performed in the two stages of the study; that is, the psychopathological groups were compared with and without controlling for answers (stage 1), and the groups of patients and non-patients were compared using the optimized range of answers (stage 2).

\section{Results}

Sixteen variables were selected from the Zulliger test to be analyzed. Stage 1 was conducted to verify whether the variables differed according to the type of administration. For that, the two groups of patients were compared, and data are presented in Table 3.1. 
Table 3.1. Comparison of variables according to the type of administration between groups of patients.

\begin{tabular}{|c|c|c|c|c|c|c|c|}
\hline Variables & $\begin{array}{c}\text { Type of } \\
\text { administration }\end{array}$ & $\mathbf{N}$ & Mean & $\begin{array}{l}\text { Standard } \\
\text { deviation }\end{array}$ & $t$ & $p$ & $d$ \\
\hline \multirow{2}{*}{$\mathrm{R}$} & R-optimized & 39 & 9.897 & 1.635 & \multirow{2}{*}{7.831} & \multirow{2}{*}{$<0.001$} & \multirow{2}{*}{1.773} \\
\hline & Comprehensive System & 39 & 6.462 & 2.199 & & & \\
\hline \multirow{2}{*}{ P } & R-optimized & 39 & 0.155 & 0.108 & \multirow{2}{*}{-0.143} & \multirow{2}{*}{0.887} & \multirow{2}{*}{-0.032} \\
\hline & Comprehensive System & 39 & 0.159 & 0.119 & & & \\
\hline \multirow{2}{*}{ AG } & R-optimized & 39 & 0.097 & 0.105 & \multirow{2}{*}{2.598} & \multirow{2}{*}{0.011} & \multirow{2}{*}{0.588} \\
\hline & Comprehensive System & 39 & 0.041 & 0.084 & & & \\
\hline \multirow{2}{*}{ COP } & R-optimized & 39 & 0.034 & 0.060 & \multirow{2}{*}{-0.413} & \multirow{2}{*}{0.681} & \multirow{2}{*}{-0.094} \\
\hline & Comprehensive System & 39 & 0.041 & 0.084 & & & \\
\hline \multirow{2}{*}{ MOR } & R-optimized & 39 & 0.047 & 0.081 & \multirow{2}{*}{0.336} & \multirow{2}{*}{0.738} & \multirow{2}{*}{0.076} \\
\hline & Comprehensive System & 39 & 0.040 & 0.107 & & & \\
\hline \multirow{2}{*}{ GHR } & R-optimized & 39 & 0.197 & 0.126 & \multirow{2}{*}{0.729} & \multirow{2}{*}{0.468} & \multirow{2}{*}{0.165} \\
\hline & Comprehensive System & 39 & 0.174 & 0.155 & & & \\
\hline \multirow{2}{*}{ PHR } & R-optimized & 39 & 0.181 & 0.154 & \multirow{2}{*}{1.273} & \multirow{2}{*}{0.207} & \multirow{2}{*}{0.288} \\
\hline & Comprehensive System & 39 & 0.133 & 0.178 & & & \\
\hline \multirow{2}{*}{ Es } & R-optimized & 39 & 0.407 & 0.206 & 666 & & \\
\hline & Comprehensive System & 39 & 0.233 & 0.215 & 3.004 & -0.001 & 0.030 \\
\hline somar & R-optimized & 39 & 0.105 & 0.107 & -1 & > 100 & ג \\
\hline - & Comprehensive System & 39 & 0.144 & 0.156 & 1.291 & 0.199 & 0.294 \\
\hline Isolation & R-optimized & 39 & 0.135 & 0.132 & -0866 & (28) & -0106 \\
\hline index & Comprehensive System & 39 & 0.168 & 0.196 & 0.000 & 0.309 & 0.170 \\
\hline We cumb & R-optimized & 39 & 0.111 & 0.230 & & & \\
\hline vasumio & Comprehensive System & 39 & 0.254 & 0.468 & (1/5 & 0.092 & -0.300 \\
\hline$X A \%$ & R-optimized & 39 & 0.856 & 0.130 & 026 & & \\
\hline Aค70 & Comprehensive System & 39 & 0.674 & 0.259 & 3.920 & -0.001 & $0.00 y$ \\
\hline W & R-optimized & 39 & 0.856 & 0.145 & 7 & 01 & $?$ \\
\hline & Comprehensive System & 39 & 0.672 & 0.242 & 4.072 & & \\
\hline$x_{11 \%}$ & R-optimized & 39 & 0.407 & 0.189 & 3801 & $<0001$ & 0861 \\
\hline & Comprehensive System & 39 & 0.231 & 0.219 & & & \\
\hline Egocentrism & R-optimized & 39 & 0.252 & 0.161 & - 72 & $0<82$ & (150 \\
\hline index & Comprehensive System & 39 & 0.223 & 0.203 & 0.104 & 0.403 & 0.159 \\
\hline$x-2-1$ & R-optimized & 39 & 0.123 & 0.120 & 80 & > & t \\
\hline$\lambda^{2}$ & Comprehensive System & 39 & 0.242 & 0.228 & 2.009 & כ & 0.034 \\
\hline
\end{tabular}


The variables were weighted according to the individual's number of answers to prevent that analyses were performed with raw data without considering that tasks were answered with and without controlling for answers. Note that seven variables presented statistically significant results. The group that answered according to the R-optimized administration obtained the highest means in $R, A G$, es, $X A \%, W D A \%$, and $X u \%$. Variable $X-\%$ had the highest mean in the group that answered according to the Comprehensive System, that is, without controlling for the number of answers. The magnitudes of the differences ranged from 0.58 to 1.77.

In stage 2, the comparison of the variables between the group of patients (who answered according to R-optimized administration) and non-patients (in which individuals with a number of answers within the optimized range were selected) was analyzed. The results are presented in Table 3.2. 
Table 3.2. Comparison of variables according to the optimized range of answers between groups of patients and non-patients.

\begin{tabular}{|c|c|c|c|c|c|c|c|}
\hline Variables & Group & $\mathbf{N}$ & Mean & $\begin{array}{l}\text { Standard } \\
\text { deviation }\end{array}$ & $t$ & $p$ & $d$ \\
\hline \multirow{2}{*}{$\mathrm{R}$} & Non-patients & 56 & 11.321 & 1.869 & \multirow{2}{*}{4.259} & \multirow{2}{*}{$<0.001$} & \multirow{2}{*}{0.805} \\
\hline & Patients & 56 & 9.946 & 1.531 & & & \\
\hline \multirow{2}{*}{$P$} & Non-patients & 56 & 1.589 & 1.058 & \multirow{2}{*}{0.449} & \multirow{2}{*}{0.654} & \multirow{2}{*}{0.085} \\
\hline & Patients & 56 & 1.500 & 1.044 & & & \\
\hline \multirow{2}{*}{$A G$} & Non-patients & 56 & 0.304 & 0.502 & \multirow{2}{*}{-3.050} & \multirow{2}{*}{0.003} & \multirow{2}{*}{-0.576} \\
\hline & Patients & 56 & 0.732 & 0.924 & & & \\
\hline \multirow{2}{*}{$\mathrm{COP}$} & Non-patients & 56 & 0.304 & 0.502 & \multirow{2}{*}{-0.175} & \multirow{2}{*}{0.861} & \multirow{2}{*}{-0.033} \\
\hline & Patients & 56 & 0.321 & 0.575 & & & \\
\hline \multirow{2}{*}{ MOR } & Non-patients & 56 & 0.393 & 0.679 & \multirow{2}{*}{0.134} & \multirow{2}{*}{0.893} & \multirow{2}{*}{0.025} \\
\hline & Patients & 56 & 0.375 & 0.728 & & & \\
\hline \multirow{2}{*}{ GHR } & Non-patients & 56 & 1. 446 & 0.989 & \multirow{2}{*}{-1.127} & \multirow{2}{*}{0.262} & \multirow{2}{*}{-0.213} \\
\hline & Patients & 56 & 1.696 & 1.334 & & & \\
\hline \multirow{2}{*}{ PHR } & Non-patients & 56 & 1.196 & 1.327 & \multirow{2}{*}{-1.372} & \multirow{2}{*}{0.173} & \multirow{2}{*}{-0.259} \\
\hline & Patients & 56 & 1. 554 & 1.426 & & & \\
\hline \multirow{2}{*}{ Es } & Non-patients & 56 & 3.857 & 2. 720 & ברד ת & ᄀ & ד1ר \\
\hline & Patients & 56 & 3. 518 & 2. 224 & 0.125 & $0.4 / 11$ & 0.131 \\
\hline somer & Non-patients & 56 & 1.143 & 1.034 & & & \\
\hline - & Patients & 56 & 0.911 & 1.049 & (1.17) & 0.241 & 0.225 \\
\hline Isolation & Non-patients & 56 & 0.201 & 0.169 & 2867 & זمि & 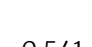 \\
\hline index & Patients & 56 & O. 121 & 0.123 & 2.802 & 0.005 & 0.541 \\
\hline WSum6 & Non-patients & 56 & 0.893 & 2.221 & -0660 & קחת & 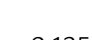 \\
\hline & Patients & 56 & 1.161 & 2. 052 & -0.003 & 0.505 & -0.125 \\
\hline Y^o\% & Non-patients & 56 & 71.132 & 18.532 & $10<5$ & $<0 \Omega 01$ & 1076 \\
\hline & Patients & 56 & 19.787 & 31.741 & $1 0 . 4 \longdiv { 4 }$ & & \\
\hline WDA\% & Non-patients & 56 & 63.511 & 18.594 & 0624 & $<0001$ & 1810 \\
\hline VUDT & Patients & 56 & 18.872 & 29.310 & $9.0<4$ & -0.001 & 1.019 \\
\hline$x_{1} \%$ & Non-patients & 56 & 29.543 & 14.122 & דראל & 0 & 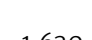 \\
\hline А & Patients & 56 & 7.135 & 13.357 & 0.021 & -0.001 & 1.030 \\
\hline Egocentrism & Non-patients & 56 & 0.226 & 0.191 & 62 & 718 & -0068 \\
\hline index & Patients & 56 & 0.238 & 0.162 & 0.302 & 0.710 & 0.000 \\
\hline$x-0$ & Non-patients & 56 & 20.569 & 12.666 & 780 & $<\cap 0 \bigcirc 1$ & 100 \\
\hline 人 & Patients & 56 & 6.273 & 13.461 & 3.109 & -0.001 & 1.094 \\
\hline
\end{tabular}


The results indicated seven statistically significant variables. The group of patients obtained the highest means in $\mathrm{AG}$, and the group of non-patients obtained the highest means in $\mathrm{R}$, Isolation index, $\mathrm{XA} \%, \mathrm{WDA} \%, \mathrm{Xu} \%$, and $\mathrm{X}-\%$. The magnitudes of the differences ranged from 0.54 to 1.97 .

\section{Discussion}

This study's objective was to verify the existence of differences in some pathological and healthy variables in a group of patients (various psychopathologies) and non-patients with an optimized range of answers in the Zulliger. The main hypothesis was that Zulliger with R-optimized administration would discriminate between the two groups. To ensure the results of this analysis were actually due to the control of responses, a previous analysis was conducted between two groups of patients. One group answered the test with R-optimized administration and the other group without controlling for responses.

The results show that almost half of the variables discriminated the two groups of patients with statistical significance. Hence, the work done in stage 1 ensured greater confidence in the interpretation that the results of the comparisons between the patient and non-patient groups could discriminate the individuals due to the optimized range of answers.

Note that seven of the selected variables presented statistically significant differences, six of which obtained the highest means in the group of non-patients, and one obtained the highest mean in the group of patients. The effects ranged from moderate to strong magnitude.

The variable concerning the number of answers $(R)$ is important because it is used to calculate the percentage and proportion of the other variables, and for this reason, it is important to control for it (Dean et al., 2007; Meyer et al., 2017). $\mathrm{R}$ is related with productivity, and ability to produce ideas (Villemor-Amaral \& Primi, 2009) and the group of non-patients obtained the highest mean, which is in line with the literature, as people with psychopathological diagnoses are more likely to present a lower number of answers (Gonçalves \& Villemor-Amaral, manuscript submitted for publication; Gonçalves et al., 2019).

Isolation index refers to withdrawal and avoidance of social contact (Villemor-Amaral \& Primi, 2009) and non-patients obtained the highest mean in this variable. This result was not expected because these are characteristics most 
commonly presented by individuals diagnosed with psychopathologies. This result does not appear statistically significant in previous studies comparing non-patients and individuals with depression (Franco \& Villemor-Amaral, 2012a; Gonçalves \& Villemor-Amaral, manuscript submitted for publishing; Villemor-Amaral \& Machado, 2011). This was the only variable in the qualitative study conducted by Franco and Villemor-Amaral (2012b), in which some of the drug-addicted individuals obtained a value above the mean. Different studies have not presented evidence over the years that this variable, in fact, assesses these characteristics, so that it is important to be cautious with this variable when using the Zulliger test.

Variable $\mathrm{XA} \%$ refers to an objective perception of reality without subjective distortions. It is strongly related to WDA\%, which indicates the possibility of adequately perceiving facts without considering distortions accruing from unusual situations (Villemor-Amaral \& Primi, 2009). This study's main findings were better than those found by Franco and Villemor-Amaral (2012a), in which the variables do not significantly discriminate individuals diagnosed with schizophrenia from individuals without this psychopathology (XA\%: $t=0.59, \mathrm{p}=0.27$; WDA\%: $t=0.88$, $p=0.51$ ). Both $X A \%$ and WDA\% present information regarding the mediation that a person makes of her/his conceptual information and the environment where s/he lives (Exner \& Sendín, 1999; Villemor-Amaral \& Primi, 2009). These are important variables to be analyzed in a group of individuals with psychopathologies. Thus, the two variables were capable of discriminating between the groups when the number of answers was controlled for, showing that non-patients present a well-established perception of reality compared to diagnosed individuals who tend to present a distorted perception, possibly due to mental health conditions.

Another variable that enabled discriminating between the groups was $\mathrm{Xu} \%$, which represents a more subjective or peculiar, but not pathological, way of making sense of reality (Villemor-Amaral \& Primi, 2009). Non-patients obtained the highest mean in this variable. It is an expected result because individuals without psychopathological diagnoses may present idiosyncratic perceptions that make some sense in reality, but do not present a severe distortion as it happens in psychotic cases, for instance.

Non-patients obtained the highest mean in variable $\mathrm{X}-\%$. This was unexpected and did not corroborate the initial hypothesis because the group of patients was expected to obtain the highest mean, considering this variable is 
related with mediation problems, perceptive distortion of reality, and difficulty in adapting, for instance (Villemor-Amaral \& Primi, 2009), which are problems most commonly found among individuals diagnosed with psychopathologies. However, it is important to note that, even though the non-patients group obtained the highest mean, it was not higher than the mean obtained in the normative population and does not compromise the WDA\% adequate level, as shown in this study. The study by Franco and Villemor-Amaral (2012b) addresses a sample of drug-addicted individuals who obtained an above the mean value in this variable. As these two results were contrasting, and due to a lack of other studies with this variable, it is impossible to state whether $X-\%$ is more recurrent in groups of patients or non-patients. A possible explanation for this unexpected result is that this variable derives from the frequency of less formal quality (FQ-), which generally is a code with higher levels of divergence between evaluators (Meyer et al., 2017), even though within an acceptable range. Additionally, in the Zullinger standardization study, the tolerance threshold for assigning this code was lower (Villemor-Amaral \& Primi, 2009), while recent studies recommend this code (FQ-) only in cases in which an individual's perception is excessively distorted (Meyer et al., 2017).

Finally, the only variable in which the group of patients obtained the highest mean was AG, representing a more hostile view of interactions with other people (Villemor-Amaral \& Primi, 2009). This variable also discriminated between the two groups when the number of answers was controlled for in the Zulliger, corroborating the hypothesis. The result was similar to that found by Gonçalves and VillemorAmaral (manuscript submitted for publication), in which the patients obtained the highest mean in this variable and also to the finding reported by Franco and Villemor-Amaral (2012b), in which some psychopathological individuals scored above the mean.

\section{Final considerations}

This study contributes to the field of psychological assessment (Hutz, 2015; Urbina, 2007), more specifically with projective methods (Cardoso \& VillemorAmaral, 2017; Fensterseifer \& Werlang, 2008). This contribution is added to initial studies in which the R-optimized administration is adapted for the Zulliger test (Gonçalves \& Villemor-Amaral, manuscript submitted for publication; 
Gonçalves et al., 2019; Villemor-Amaral et al., 2016), targeting an optimized range of responses. This study was motivated by previous studies suggesting that the number of answers in the Zulliger test interferes with the instrument's remaining variables (Villemor-Amaral \& Cardoso, 2012; Villemor-Amaral et al., 2016).

Therefore, we verified that, when Zulliger is administered controlling for the number of answers, that is, using the R-optimized administration (Dean et al., 2007; Meyer et al., 2017), the variables discriminated between patients and non-patients. Among the 16 variables selected for this study, seven differentiated between the two groups, namely, R, Isolation index, XA\%, WDA\%, Xu\%, X-\% and AG. The results of $\mathrm{XA} \%$ and WDA\% were the main results to discriminate between people with and without psychopathologies for two reasons. First, these variables indicate the way individuals translate or interpret information accruing from their environments, an important characteristic to be assessed in cases of psychopathologies. The second reason accrues from empirical data, in which these variables obtained the largest magnitude effects in this study. Additionally, Isolation index is a variable that should be analyzed with caution because of its unexpected result and also due to scarce literature to corroborate findings.

One of the sample's characteristics is that the patients' group was composed of people with different psychopathologies. Most studies addressed individuals with a single diagnosis. In this study, however, the interest was to identify variables that could show evidence of changes in perception and thinking aspects, common in psychopathological conditions, and variables that indicate healthy psychological functioning. Hence, the objective was not to identify the individuals' specific type of psychopathology.

This study's limitations include the impossibility of matching the sample according to educational level because this information was lost in one of the databases. Another limitation is that a portion of the sample was composed of individuals from the Zulliger's normative results (Villemor-Amaral \& Primi, 2009), who answered the instrument without controlling for the number of answers. Even though those individuals with a number of answers within the optimized range were selected, it would be ideal for collecting data using R-optimized administration in both groups. Hence, the generalization of results should be made with caution, considering the sample's characteristics and size. Therefore, further studies should be conducted addressing a larger number of participants, with groups of patients 
and non-patients using the R-optimized administration, considering smaller differences in time, and verifying whether this study's findings are corroborated.

\section{References}

Cardoso, L. M., \& Villemor-Amaral, A. E. (2017). Critérios de cientificidade dos métodos projetivos. In M. R. C. Lins, \& J. C. Borsa (Eds.), Avaliação Psicológica: Aspectos teóricos e práticos (pp. 159-172). Petrópolis: Vozes.

Cardoso, L. M., Gomes, G. V. A., Pacheco, F. P., \& Dias-Viana, J. L. (2018). Análise da produção de artigos científicos brasileiros sobre o Teste de Zulliger. Interação em Psicologia, 22(3), 139-150. doi:10.5380/psi.v22i3.45821

Dean, K. L., Viglione, D. J., Perry, W., \& Meyer, G. J. (2007). A method to optimize the response range while maintaining Rorschach Comprehensive System validity. Journal of Personality Assessment, 89(2), 149-161. doi:10.1080/00223890701468543

Exner, J. E., \& Sendín, C. (1999). Manual de interpretação do Rorschach para o sistema compreensivo. São Paulo: Casa do Psicólogo.

Fensterseifer, L., \& Werlang, B. S. G. (2008). Apontamentos sobre o status científico das técnicas projetivas. In A. E. Villemor-Amaral, \& B. S. G. Werlang (Eds.), Atualizações em métodos projetivos para avaliação psicológica (pp. 15-33). São Paulo: Casa do Psicólogo.

Franco, R. R. C., \& Villemor-Amaral, A. E. (2009). Validade concorrente entre provas de personalidade: Zulliger-SC e Pfister. Revista Psicologia e Saúde, 1(1), 50-59. doi:10.20435/pssa.v1i1.13

Franco, R. R. C., \& Villemor-Amaral, A. E. (2012a). O Zulliger e as constelações do Rorschach no Sistema Compreensivo. Avaliação Psicológica, 11(1), 141-152. Retrieved from http://pepsic.bvsalud.org/pdf/avp/v11n1/v11n1a13.pdf

Franco, R. R. C., \& Villemor-Amaral, A. E. (2012b). Validade incremental do Zulliger e do Pfister no contexto da toxicomania. Psico-USF, 17(1), 73-83. doi:10.1590/ S1413-82712012000100009

Gonçalves, A. P., \& Villemor-Amaral, A. E. (2020). Zulliger aplicação R-otimizado na avaliação de características depressivas. Paidéia. Manuscript submitted for publication.

Gonçalves, A. P., Zuanazzi, A. C., \& Villemor-Amaral, A. E. (2019). Aplicação R-otimizada no Zulliger: Evidências de validade com pacientes depressivos. Avaliação Psicológica, 18(2), 111-120. doi:10.15689/ap.2019.1802.16215.01 
Grazziotin, J. B. D., \& Scortegagna, S. A. (2016). Revisão de pesquisas brasileiras sobre o teste de Zulliger publicadas em artigos. Avaliação Psicológica, 15(2), 227-235. doi:10.15689/ap.2016.1502.11

Hutz, C. S. (2015). O que é avaliação psicológica: Métodos, técnicas e testes. In C. S. Hutz, D. R. Bandeira, \& C. M. Trentini (Eds.), Psicometria (pp. 11-22). Porto Alegre: Artmed.

JASP Team (2018). JASP (Version 0.9.2) - [Computer software]. Retrieved from https:// jasp-stats.org/

Meyer, G. J, Viglione, D. J., Mihura, J. L., Erard, R. E., \& Erdberg, R. (2017). Rorschach sistema de avaliação por desempenho manual de aplicação codificação e interpretação e manual técnico (D. R. Silva \& F. K. Miguel, Trans.). São Paulo. Hogrefe.

Urbina, S. (2007). Fundamentos da testagem psicológica. Porto Alegre: Artmed.

Villemor-Amaral, A. E., \& Cardoso, L. (2012). Validade convergente do tipo de vivência (EB) no teste de Zulliger/SC. Psico, 43(1), 109-115. Retrieved from http://revistaseletronicas.pucrs.br/fo/ojs/index.php/revistapsico/article/view/11105/7625

Villemor-Amaral, A. E., \& Machado, M. A. S. (2011). Indicadores de depressão do Zulliger no Sistema Compreensivo (ZSC). Paidéia, 21(48), 21-27. doi:10.1590/S0103$863 \times 2011000100004$

Villemor-Amaral, A. E., \& Primi, R. (2009). Teste de Zulliger no Sistema Compreensivo - ZSC: Forma individual. São Paulo: Casa do Psicólogo.

Villemor-Amaral, A. E., Pianowski, G., \& Carvalho, L, F. (2016). Issues about color, human movement and number of responses in the Zulliger test. Rorschachiana, 37(2), 95113. doi:10.1027/1192-5604/a000068

Zulliger, H., \& Salomon, F. (1970). El test Z: Um test individual y colectivo. Buenos Aires: Kapelusz.

\section{Authors notes}

Anna Elisa de Villemor-Amaral, Post-Graduate Program in Psychology (PPGSSP), São Francisco University (USF); Gabriel Vitor A. Gomes, Post-Graduate Program in Psychology (PPGSSP), São Francisco University (USF).

Correspondence concerning this article should be addressed to Anna Elisa de Villemor-Amaral, Rua Waldemar César da Silveira, 105, Jardim Cura D’Ars, Campinas, SP, Brazil. CEP 13045-510.

E-mail: anna.villemor@usf.edu.br 